\title{
The Ross procedure: total root technique
}

\author{
Elbert E. Williams, Ismail El-Hamamsy \\ Department of Cardiovascular Surgery, Mount Sinai Hospital, Icahn School of Medicine at Mount Sinai, New York, USA \\ Correspondence to: Ismail El-Hamamsy, MD, PhD. Department of Cardiovascular Surgery, Mount Sinai Hospital, 1190 Fifth Avenue, New York \\ 10029, USA. Email: ismail.el-hamamsy@mountsinai.org.
}

Submitted Nov 05, 2020. Accepted for publication Jun 18, 2021.

doi: 10.21037/acs-2020-rp-229

View this article at: https://dx.doi.org/10.21037/acs-2020-rp-229

\section{Clinical vignette}

A fifty-four-year-old man with a history of hypertension, hyperlipidemia and cigarette smoking presented to hospital following a syncopal episode. He reported worsening shortness of breath and dyspnea on exertion. A comprehensive workup revealed severe bicuspid aortic stenosis [mean gradient: $44 \mathrm{mmHg}$ and aortic valve (AV) area: $0.62 \mathrm{~cm}^{2}$ ], preserved left ventricular function and nonsignificant coronary artery disease. Computerized tomography scan showed a $42 \mathrm{~mm}$ ascending aorta. Given his age, overall health, cardiac function, and anticipated life expectancy $>15$ years, a Ross procedure was planned. When performed in centers of expertise, the Ross procedure provides optimal long-term survival, hemodynamics and quality of life (1). However, the safety and long-term durability of the operation depend on various technical factors, which we aim to detail in this video.

\section{Surgical techniques}

\section{Preparation and exposition}

After general anesthesia is induced, transesophageal echocardiography (TEE) is performed, carefully measuring dimensions of the aortic annulus, sinuses of Valsalva, sinotubular junction (STJ) and ascending aorta. AV phenotype and commissural orientation are carefully examined. Pulmonary valve function and annular diameter are evaluated, with trace-to-mild central pulmonary regurgitation being a usual benign finding. The patient is placed in a supine position and a midline sternotomy is performed. Cardiopulmonary bypass (CPB) is established via cannulation of the aortic arch using a Seldinger technique and bicaval venous cannulation. A left ventricular vent is inserted via the right superior pulmonary vein. The heart is arrested using del Nido cardioplegia via an antegrade cannula and subsequent doses are administered via selective antegrade coronary cannulas.

\section{Operation}

After cardioplegic arrest, the aorta is incised $5 \mathrm{~mm}$ distal to the STJ. The AV is excised and the annulus decalcified. The aortic root is inspected noting annular diameter, position and heights of the commissures and raphe, and coronary locations. The coronary buttons are then mobilized. The remaining native aortic tissue of the non-coronary sinus and the left-right commissure are left intact to later use as external autograft support. The pulmonary artery (PA) is harvested in a top-down approach starting 3-5 mm proximal to the takeoff of the right PA. Care should be taken to avoid damaging the left coronary button, left anterior descending and first septal perforator. The harvested autograft is trimmed circumferentially leaving $2-3 \mathrm{~mm}$ of infundibular muscle. Using interrupted 4-0 polypropylene sutures, the autograft is implanted in a deep sub-annular position. The sutures are passed $1 \mathrm{~mm}$ above the aortic annulus and exit $2-3 \mathrm{~mm}$ below. The needle is then placed at the pulmonary cusp hinge point and driven superiorly to exclude the thin rim of infundibular muscle. It is essential to maintain symmetry while implanting the pulmonary valve and place the neo-commissures at $120^{\circ}$ at the aortic annular level to maintain valve competence. Subsequently, the coronary buttons are implanted into the autograft root in the body of their respective sinuses below the STJ. Before the aortic anastomosis is completed, a large $(>28 \mathrm{~mm})$ pulmonary homograft is implanted. A running 5-0 polypropylene suture is used to first complete 
the distal anastomosis, then a 4-0 suture for the proximal, using partial-thickness passes through the interventricular septum to avoid catching the septal perforator. Returning back to the autograft, excess supra-commissural PA is excised, leaving 2-3 $\mathrm{mm}$ of tissue above the commissures. In cases of ascending aorta dilatation $\geq 38 \mathrm{~mm}$ or mismatch between the autograft STJ and ascending aorta, a short 26 or $28 \mathrm{~mm}$ Dacron interposition graft is implanted. This serves to bridge the mismatch and stabilize the STJ, helping prevent secondary autograft regurgitation in the long-term. After weaning from $\mathrm{CPB}$ and protamine administration, the remaining native aortic tissue of the non-coronary sinus and the left-right commissure are tacked to the interposition graft to provide external, non-restrictive support to the autograft root.

\section{Completion}

Post-CPB TEE demonstrated normal biventricular function with no aortic insufficiency with a mean autograft gradient of $5 \mathrm{mmHg}$. There was no pulmonary regurgitation or gradient. The patient was extubated within two hours of admission to the intensive care unit. His post-operative course was uneventful and the patient was discharged home on post-operative day four.

\section{Comments}

\section{Clinical results}

Using this technique, we have performed >500 Ross procedures since 2010 . Of those, $15 \%$ were redo operations, $6 \%$ had active endocarditis and $58 \%$ required concomitant procedures. There were two operative mortalities $(0.4 \%)$, both occurring within the first 100 cases of our series. Two patients required reintervention for early autograft failure secondary to primary autograft regurgitation without sinus dilation, likely attributable to poorly controlled hypertension. Additionally, two patients required transcatheter reintervention for pulmonary homograft dysfunction. Average mean autograft gradient at discharge was $4 \mathrm{mmHg}$. Longitudinal echocardiographic follow-up demonstrated stable aortic root dimensions and no changes in autograft function up to ten years after surgery.

\section{Advantages}

This technique has been tailored to reduce the risk of late autograft dilatation and subsequent neo-aortic regurgitation by addressing each area of failure: the autograft annulus, the sinuses of Valsalva, the STJ and pulmonary homograft dysfunction. The autograft is placed deep into the LVOT to provide autograft annular support as the devascularized infundibular muscle provides no structural support to the pulmonary valve. In patients with a dilated aortic annulus and aortic regurgitation, an external aortic ring annuloplasty is added to match aortic and pulmonary dimensions and provide long-term freedom from dilatation (2). Dilatation of the sinuses of Valsalva is avoided by using the native aortic tissues of the non-coronary sinus and left-right commissure as external support to the autograft root (3). This, with strict blood pressure control keeping systolic pressures $<110 \mathrm{mmHg}$ for six to twelve months, results in stable neo-aortic root dimensions. The STJ is stabilized by excision of supra-commissural PA tissue. In situations of mismatch between autograft and aortic dimensions, a short interposition graft prevents STJ dilatation. Homograft dysfunction is addressed by routinely oversizing the chosen homograft ( $\geq 28 \mathrm{~mm}$ ), using decellularized homografts, and using non-steroidal anti-inflammatory medications for 6 months post-operatively (4). While these steps do not eliminate homograft dysfunction, most reinterventions can be done percutaneously.

\section{Caveats}

Much like any complex operation, there is a learning curve to the Ross procedure (5). The Ross is a technically involved operation and outcomes are intimately related to surgical technique. However, when done in high volume centers with dedicated aortic root surgeons, this technique is reproducible, safe and provides excellent long-term outcomes.

\section{Acknowledgments}

Funding: None.

\section{Footnote}

Conflicts of Interest: Both authors have completed the ICMJE uniform disclosure form (available at https://dx.doi. org/10.21037/acs-2020-rp-229). The authors have no conflicts of interest to declare.

Open Access Statement: This is an Open Access article 
distributed in accordance with the Creative Commons Attribution-NonCommercial-NoDerivs 4.0 International License (CC BY-NC-ND 4.0), which permits the noncommercial replication and distribution of the article with the strict proviso that no changes or edits are made and the original work is properly cited (including links to both the formal publication through the relevant DOI and the license). See: https://creativecommons.org/licenses/by-nc-nd/4.0/.

\section{References}

1. Aboud A, Efstratios I, Fujita B, et al. Long-term outcomes of patients undergoing the Ross Procedure. J Am Coll Cardiol 2021;77:1412-22.

2. Basmadjian L, Basmadjian AJ, Stevens LM, et al. Early

Cite this article as: Williams EE, El-Hamamsy I. The Ross procedure: total root technique. Ann Cardiothorac Surg 2021;10(4):546-548. doi: 10.21037/acs-2020-rp-229 results of extra-aortic annuloplasty ring implantation on aortic annular dimensions. J Thorac Cardiovasc Surg 2016;151:1280-5.e1.

3. Bouhout I, Ghoneim A, Tousch M, et al. Impact of a tailored surgical approach on autograft root dimensions in patients undergoing the Ross procedure for aortic regurgitation. Eur J Cardiothorac Surg 2019;56:959-67.

4. Chauvette V, Bouhout I, Tarabzoni M, et al. Pulmonary homograft dysfunction after the Ross procedure using decellularized homografts-a multicenter study. J Thorac Cardiovasc Surg 2020. [Epub ahead of print]. doi: 10.1016/j.jtcvs.2020.06.139.

5. Bouhout I, Ghoneim A, Poirier N, et al. Impact of the Learning Curve on Early Outcomes Following the Ross Procedure. Can J Cardiol 2017;33:493-500. 